\title{
Martín Fernando Duarte Gómez
}

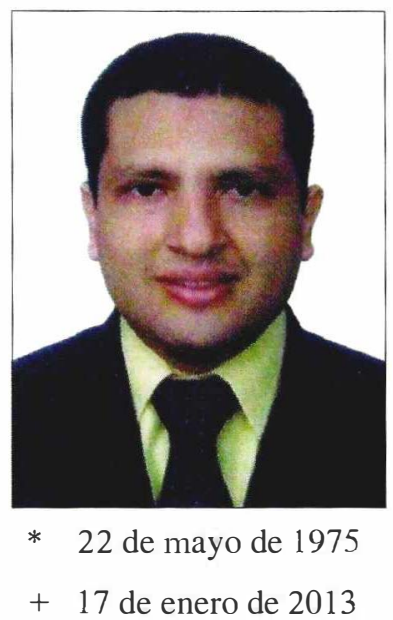

Desde la primaria Martín Fernando suspiraba por el deporte, muchas "preseas" logró como atleta allá en su barrio cucuteño. Luego encontró la razón de su espíritu deportivo en el fútbol, donde conformó varios equipos. Fue portero, defensa y delantero; en la Salle de Villavicencio, práctico su fútbol y no hubo semana que no jugara, cada vez que llegaba a una ciudad exigía que lo llevaran al estadio; en su "Campin" del alma se sentía realizado y más, con su divisa azul. En vano, su padre le hablaba de su adorado "Cúcuta deportivo", para el bogotano Martin Fernando era Millonarios el que vio ganar.

La vida lo llevo a confundirse con sus jugadores... sabía que viajaría con la segunda de "Millos" a Chile como "Médico Deportólogo" y no se cambiaba por nadie. Cuando iba a Villavicencio a despedirse de su adorada esposa, de sus hijos del alma y sus viejos, se fue a la eternidad.

Don Fernando, su padre dijo al evocar a Becquer:"Al brillar un relámpago nacemos, cuan dura su fulgor cuando morimos...la gloria, el amor que corremos, sombras de un sueño que perseguimos, despertar es morir" y luego sin dudar afirmó: "Mas aquel a quien los dioses aman, muere pronto". El médico, el estudioso, el consagrado, el buen hijo, el amante esposo y padre, el fiel amigo, el jefe de la manada, el deportista. Aquel que siendo un estudiante de medicina estuvo al lado del científico Patarroyo, después consiguió ser gerente en salud y auditor médico y como residente presenció las 21 medallas del Meta en los últimos Juegos Nacionales, en los que por primera vez en la historia consiguiera tres de oro que Martín pudo levantar.

Al llegar a la sala nos asombró la copiosa ofrenda floral que recibió Martín Fernando, fue estrecho el lugar para tanto afecto. Sacamos fuerzas para acercarnos a los suyos y transidos de dolor invitamos a Diana Marcela su esposa, a sus hijos Sergio, Santiago y Sofía así como a sus padres, para que en agosto recibieran otro más de sus tantos títulos profesionales, el grado póstumo como Médico de la Actividad Física y del Deporte de la FUCS.

Entonces, nos trasladamos en el tiempo y vimos ingresar al médico llanero, con su andar lento y pausado, su hablar particularmente enredado, analizando cada situación, cada comentario y cada proceso para auditar su origen y contenido, para poner en acción su espíritu gerencial y terminar modificando tantas cosas del servicio con el objetivo de incrementar su productividad y eficiencia. Gracias Martín.

Diana su esposa dijo: "Es que tú estás terriblemente presente entre nosotros, desde allá, donde esperas la resurrección, contamos las bendiciones de aquel a quien amo más que nadie y quien siempre te quiso consigo".

Juan Carlos Galvis Rincón, MD

Jefe del Posgrado de Medicina de la Actividad Física y del Deporte - FUCS Jefe del Servicio de Rehabilitación Hospital Infantil Universitario de San José 